\title{
Implementation Remains the Achilles Heel of the African Union: A Study of the African Peer-Review Mechanism (APRM)
}

Imani faoko*

\begin{abstract}
The potential power of Africa is undisputed. The continent is home to a large, young population and is a potential economic powerhouse in the world. In order to realise its full potential, the African Union (AU) must guide the continent. The AU, has however, repeatedly faltered in this regard. The implementation mechanisms of the AU seem to be its Achilles' heel. The AU suffers no shortage of well-formulated policies; instead it suffers from a chronic inability to follow up on these policies. This paper maps the formation of the AU, the promise it held and the factors that limit the ability of the AU to implement its programs and policies. The paper then briefly examines the African Peer Review Mechanism (APRM) looking at the problems of implementation it has faced and how these may be remedied.
\end{abstract}

\section{The Promise of the African Union}

In 2002, when the African Union (AU) was formed it was hailed as a new dawn for the African continent. The new body was seen as an invigorated and refreshed institution that would tackle the problems facing the continent. Its predecessor, the Organisation of African Unity (OAU) had largely lost its grip on the crises in the continent ${ }^{1}$ and had largely failed to act on major issues unfolding on the continent. ${ }^{2}$ Its influence had waned and instead the OAU had earned the sarcastic title of a 'Club of Africa's Big Men.'

\footnotetext{
* The author is a student at Strathmore Law School in Nairobi, Kenya.

Editorial, The Mirror, Accra (1993).

For instance, the 1994 Rwanda Genocide.

Okumu W, 'The African Union: Pitfalls and prospects for uniting Africa', 62 Journal of International Affairs, (2009), 102.
} 
The OAU was in many ways a toothless dog with its constitutive charter rendering the OAU's executive and administrative branches ineffective by according them only limited powers. Further, the resolutions of the OAU Assembly were not legally binding on members, which made the organization no more than a deliberative forum to 'talk shop' and not follow up with implementation.

As the number of armed conflicts in the continent rose and dictatorial governments became increasingly more restrictive, it became clear that the greatest achievement of the OAU would remain political emancipation of colonized states. ${ }^{5}$ In order to tackle the emerging issues on the continent, a different, or revamped, body was needed.

In considering the achievements of the OAU, the Algiers Declaration ${ }^{6}$ affirmed that the organisation had 'played an irreplaceable role in the affirmation of political identity and the realisation of the unity of our continent.' ${ }^{7}$ Indeed, the role of the OAU in the anti-apartheid struggle in South African cannot be understated. ${ }^{8}$ However, the Assembly of Heads of States and Government took notice of the fact that the second millennium, characterized by colonization, had come to an end and the struggle for self-governance had been successful. ${ }^{9}$ Instead, the third millennium, characterized by challenges such as globalization, international conflict and trends in the world economy that were unfair to African countries, had arrived. ${ }^{10}$ For this reason, the Heads of States and Government recognized the need for 'a mutually beneficial and genuine international partnership; a partnership based on a balance of interests and mutual respect.' ${ }^{\prime 1}$

The Algiers Declaration was followed by the Sirte Declaration, ${ }^{12}$ which formally announced the intention to form the AU. The declaration read in part as follows:

\footnotetext{
Center for Conflict Resolution, The African Union at ten: Problems, progress, and prospects, 2012, 6.

Nmehielle V and Katherine A, 'The African Peer Review Mechanism under the African Union and its initiative: the new partnership for Africa's development' 98 Proceedings of the Annual Meeting of The American Society of International Law, 2004, 240.

Algiers Declaration, 1999.

Algiers Declaration, 1999.

CCR, The African Union at ten: Problems, progress, and prospects, 7.

Algiers Declaration, 1999.

Algiers Declaration, 1999.

Algiers Declaration, 1999.

Sirte Declaration, 1999.
} 
'In order to cope with those challenges and to effectively address the new social, political and economic realities in Africa and in the world, we are determined to fulfil our peoples' aspirations for greater unity in conformity with the objectives of the OAU Charter and the Treaty establishing the African Economic Community. It is also our conviction that our Continental Organisation needs to be revitalised in order to be able to play a more active role and continue to be relevant to the needs of our peoples and responsive to the demands of the prevailing circumstances ${ }^{13}$

Following the Sirte Declaration, the Council of Ministers and the SecretaryGeneral of the OAU were tasked with formulating the framework that would govern this new partnership. ${ }^{14}$ The Constitutive Act of the AU was the fruit of this labour. ${ }^{15}$

The Constitutive Act establishes the AU as a functionalist organization ${ }^{16}$ whose aim is to achieve greater unity and solidarity among the African people(s). The Act provides that the AU will seek to accelerate the political and socioeconomic integration of the continent ${ }^{17}$ as well as promote peace, security and stability. ${ }^{18}$ More important for this paper, the Act also provides that the AU will aim to promote democratic principles and institutions, popular participation and good governance. ${ }^{19}$

\section{The African Union Thirteen Years On}

Thirteen years after its formation, the AU has nonetheless struggled to make an impact in the way that was previously hoped. While the number of multi-party political systems in Africa has increased, the quality of democracy in many countries has been arguably declining since 2005, in particular, the curtailing of political rights during elections. ${ }^{20}$ In a similar manner, while the number of civil wars has decreased since the creation of the AU from eight in 2002 to four in 2012, the number of localised crises that turn violent have risen. ${ }^{21}$ Further, the

\footnotetext{
13 Paragraph 6, Sirte Declaration, 1999.

14 Article 8(3) and (4), Organisation of African Unity (Assembly of Heads of State and Government), Sirte Declaration 1999.

15 The Act was adopted on $11^{\text {th }}$ July 2000 and entered into force on $26^{\text {th }}$ May 2001.

16 A functionalist organisation is one that focuses on common interests shared by states rather than self-interest.

17 Article 3 (c), The Constitutive Act of the African Union (2002).

18 Article 3 (f), The Constitutive Act of the African Union (2002).

19 Article 3 (g), The Constitutive Act of the African Union (2002).

20 CCR, The African Union at ten: Problems, progress, and prospects, 2012, 3.

21 CCR, The African Union at ten: Problems, progress, and prospects, 2012, 3.
} 
AU has also done little to effectively intervene in civil conflicts in countries such as the Democratic Republic of Congo and South Sudan. ${ }^{22}$

The global scourge of terrorism has not spared the African continent with groups such Boko Haram and Al-Shabaab proving to be a menace in West and East Africa respectively. ${ }^{23}$ While the continent has progressive legal instruments aimed at fighting terrorism, ${ }^{24}$ once again implementation has proven to be difficult. ${ }^{25}$ In fact the AU Peace and Security Council ${ }^{26}$ openly noted that:

'Despite the progress made in developing a comprehensive normative and operational counter-terrorism framework, serious gaps continue to exist in terms of implementation and follow-up, thus undermining the effectiveness of Africa's response to the threat of terrorism and violent extremism. ${ }^{27}$

The AU has also largely failed to assert itself on the international stage to the extent that was hoped. This is easily illustrated by the action taken by the United Nations (UN) in the Libyan conflict in 2011. The UN sidestepped the AU in allowing the intervention of the North Atlantic Treaty Organisation (NATO) in the country- despite the fact that intervention went against the AU's plan for peace in Libya. ${ }^{28}$ What is perplexing is that the three African states on the Security Council at the time voted in favour of this action. ${ }^{29}$

Therefore, it is mostly clear that the AU has struggled to live up to expectations.

22 Kimenyi M, 'An African Union for an emerging Continent: Reforms to increase effectiveness' The Brookings Institution: Africa Growth Initiative, 2015, 32.

23 In 2014, Boko Haram and related actors committed hundreds of attacks in Nigeria resulting in over 5, 000 casualties while in Kenya attacks by Al-Shabaab resulted in 200 deaths- Kenya's deadliest year against the group. See: US Department of State, Country Reports on Terrorism 2014, 11.

24 Including the 2001 Dakar Declaration Against Terrorism, 2002 AU Plan Of Action On The Prevention And Combating Of Terrorism, 2004 Protocol To The OAU Convention On The Prevention And Combating Of Terrorism and The 2014 Resolution 276 On Terrorist Acts In Africa

25 Allison S, 'Good talk, not enough action: The AU's counter-terrorism architecture, and why it matters' Policy Brief for Institute of Security Studies (2015), 5.

26 The Peace and Security Council (PSC) is the AU's standing decision-making body responsible for the maintenance of continental peace and security. It has 15 members, elected by the AU Executive Council on regional basis (three from Central Africa; three from East Africa; two from North Africa; three from Southern Africa; and four from West Africa).

27 Communiqué of the Peace and Security Council, 455th meeting at the level of Heads of State and Government, Nairobi, 2 November 2014.

28 CCR, The African Union at ten: Problems, progress and prospects, 2012, 11.

29 South Africa, Nigeria and Gabon voted 'Yes' to UN Resolution 1973 which formed the legal basis for military intervention in Libya. See more at: http://www.un.org/press/en/2011/sc10200.doc. html on January 202016. 


\section{The Tale of the Achilles Heel}

The term 'Achilles heel' is derived from the tale of Achilles as told in Greek mythology. ${ }^{30}$ Achilles was the son of a Greek goddess, Thetis. When Achilles was a child, it was foretold that he would die young. Upon hearing this, Thetis was distraught. She then formulated a plan to take her son to River Styx, which was rumoured to offer powers of invulnerability. She dipped her son's body in the water and believed that he had become invulnerable. However, as fate would have it, this was not the case. Thetis had held her son by his ankle and so, while the rest of his body was washed in the magical water, his ankle-covered by her thumb and forefinger-was not. Achilles grew to be a great soldier and man of war who survived many great battles. However, during the Trojan War a poisonous arrow shot at him lodged in his heel - his vulnerable spot. The poison killed him shortly after.

The term Achilles heel is used to mean an area of weakness or a vulnerable spot, in spite of overall strength. It can be described as a powerful person's fatal weakness—one's hamartia.

The potential power of the African continent is not contested. However, led by the AU, Africa has consistently failed to live up to this potential. The AU has elaborative policy documents and Africa is home to some of the most progressive Constitutional Bills of Rights in the world. ${ }^{31}$ However, the weight of these words is weakened when there is a failure to implement.

The AU faces a myriad of challenges: corruption, rogue leaders, lack of financing, poor co-ordination, and lack of political goodwill. However, the problem that this paper will focus on is the lack of implementation - termed as the Achilles heel of the AU.

Without an implementation track record, the power of the AU is reduced to nothing - it is the fatal weakness of a potentially powerful body. This is because even solving the other AU problems requires implementation. For instance, on corruption, in 2003 the AU adopted The African Union Convention on Preventing and Combating Corruption ${ }^{32}$ to fight rampant political corruption on the African continent. The Convention places several obligations on

\footnotetext{
30 Olympus Library, 'The Tale of Achilles' http://wserver.scc.losrios.edu/ waxmanr/87online/ student_sites/morco_luisa/myths/tale_of_achillies.html on 26 November 2015.

31 The South African Bill of Rights is progressive in terms of its provisions on anti-discrimination, while the Kenyan Bill of Rights is progressive in terms of its protection of socioeconomic rights.

32 The African Union convention on preventing and combating corruption, 2003.
} 
signatories including requirements that officers in public service declare assets and sign codes of conduct, whistleblower protection, procurement standards and accounting standards. It is also requires states to establish, maintain and strengthen independent national anti-corruption authorities. The AU Convention also calls for the criminalization of a wide range of offences, including illicit enrichment, and contains a broad definition of the term 'public official.' It also provides a framework for the confiscation and seizure of assets. ${ }^{33}$ Further, pursuant to Article 22 of the Convention, The African Union Advisory Board on Corruption, an autonomous organ, was established within the AU.

However, after the Convention was adopted Transparency International (TI) noted that, while the document was encouraging, 'implementation must now be the top priority. ${ }^{34}$ Yet four years later some countries still had legal gaps in their systems that hampered the application of the convention..$^{35}$ Furthermore in 2013, a report by the African Progress Panel presented at the World Economic Forum on Africa 2013 found that the continent is losing more through illicit financial outflows than it receives in aid and foreign direct investment. ${ }^{36}$ It found that illicit outflows cost the continent just over thirty-eight and twenty-five billion US dollars respectively between 2008 and $2010 .^{37}$

Therefore, it is clear that even if the other AU issues were to be solved, implementation would still be crucial. Without implementation, declarations, policies, protocols and conventions (aimed at solving whatever problem the AU faces) simply remain statements of intentions without actual follow-through. ${ }^{38}$ This is why failure to implement remains the main area point of vulnerability of the AU.

At this point it is important to answer the question, 'what does implementation entail?' Implementation is the ability of the AU to move past rhetoric and towards action. To achieve this, the AU needs to have a clear strategy to ensure actual outcomes from policies. Implementation refers to the complex process

33 'Transparency International Commentary on The African Union Convention on Preventing and Combating Corruption', http://archive.transparency.org/global_priorities/international_ conventions/conventions_instruments/au_convention\#sthash.opwQ3oFv.dpuf on 20 January 2016.

34 Transparency International Press Release 'Towards effective anti-corruption tools in Africa' 17 April 2007 http:/ /archive.transparency.org/news_room/in_focus/2007/uncac_africa on 20 January 2016.

35 Transparency International Press Release 'Towards effective anti-corruption tools in Africa' 17 April 2007 http://archive.transparency.org/news_room/in_focus/2007/uncac_africa on 20 January 2016. African Progress Panel, Equity in Extractives Stewarding Africa's natural resources for all, 2013, 66.

African Progress Panel, Equity in Extractives Stewarding Africa's natural resources for all, 2013, 66.

3 Kimenyi M, 'An African Union for an emerging Continent: Reforms to increase effectiveness', 31. 
of putting a policy into practice by a variety of mechanisms and procedures involving a wide and diverse range of actors. ${ }^{39}$ As used in this paper, it refers to follow-up mechanisms that the AU has at its disposal, or lacks. These are mechanisms that ensure that African states are accountable to the institution, fulfil their obligations and comply with instructions and that policies move from paper to practice. Implementation tests policies by gauging whether the policies as written down are in congruence with the realities on the ground..$^{40}$

Admittedly, implementation and compliance can never be perfect. The gaps that exist may not even be a result of any express action to bar compliance. ${ }^{41} \mathrm{In}$ deed, even institutions such as the European Union (EU) — which has much to be admired in terms of ensuring compliance, — suffer from these implementation gaps. ${ }^{42}$ What is of concern in the case of the AU is the extent of these gaps. In this respect, the $\mathrm{AU}$ tends to be a norm-setter rather than an implementer having successfully drafted several important policy documents but not having implemented them. ${ }^{43}$ This 'implementation crisis' also befell the OAU, with the organization's initiatives regularly failing to attain sufficient commitment from the continent's leaders and the international community. ${ }^{44}$

Before proceeding, it is important to delineate some issues in this respect. An analysis of the implementation powers of the AU with regard to governance areas such as democracy, good-governance and economic progress should necessarily be differentiated from the ability of the AU to implement its agenda with regard to conflict and war. While conflict and war do indeed fall under the umbrella of political governance, they will necessarily be severed.

This delineation is informed by the fact that conflict and war are usually the final—or most extreme, result of bad governance. ${ }^{45}$ They signify the final breakdown of the state as opposed to other manifestations of political governance

39 Dimitrakopoulos D and Richardson J, 'Implementing EU public policy' in Richardson J (ed), European Union: Power and Policy-Making, Routledge, 2001, 1.

40 Dimitrakopoulos D and Richardson J, 'Implementing EU public policy', 1.

41 See generally: Dimitrakopoulos D and Richardson J, 'Implementing EU Public Policy.'

42 For instance, the area of Environmental Law has posed a significant challenge for the EU in implementing policies across all member countries. See generally: European Union Network for the Implementation and Enforcement of Environmental Law, Challenges in the practical implementation of EU Environmental Law and how impel could help overcome them, 2015.

43 CCR, The African Union at ten: Problems, progress, and prospects, 16.

44 Franke B, 'Competing Regionalisms in Africa and the Continent's emerging security architecture', 9 African Studies Quarterly (2007), 51.

45 Mathoho M, 'An African Peer Review Mechanism: A panacea for Africa's governance challenges?' 29 Policy Brief for Centre of Policy Studies (2003), 11. 
such as civil and political rights and constitutional democracy, whose absence does not necessarily bring the state to a standstill. For this reason, the powers of the AU with respect to these two kinds of issues are quite different. For instance, the AU is expressly empowered to intervene in grave circumstances such as genocide, war crimes and crimes against humanity ${ }^{46}$ and when states request its intervention to help restore peace and security. ${ }^{47} \mathrm{In}$ all these situations, the results per se of bad political governance have already been witnessed.

In contrast, the Constitutive Act does not specifically empower the Union to interfere in instances of bad governance. The sanction powers of the AU may be triggered in the case of default in payment of contribution to the budget. ${ }^{48}$ These sanctions may also be imposed on 'any member state that fails to comply with the decisions and policies of the Union' ${ }^{39}$ and the sanctions to be imposed include 'the denial of transport and communications links with other member states, and other measures of a political and economic nature to be determined by the Assembly. 50

This second category is quite broad and can arguably be used to impose sanctions as a result of bad governance. However, this provision is vague, possibly even giving the AU unlimited powers. ${ }^{51}$ This is perhaps the reason it has never been used. Granted, the power to intervene in the issues of bad governance would risk interfering with the sovereignty of the various states and thus should be the last option. Therefore, the solution lies in ensuring compliance rather than punishment for failure to comply after the fact.

For the purposes of this paper, the problem of implementation is to be considered separately from the powers of the $\mathrm{AU}$ to intervene in conflict and war and is instead to be considered in light of the AU's other enforcement mechanisms.

Despite this distinction, what is interesting to note is that even in situations where the AU has the express right to intervene, it has largely been ineffective due to lack of political will and trigger mechanisms. ${ }^{52}$ Therefore, if these express

\footnotetext{
Article 4 (h)The Constitutive Act of The African Union (2002).

Article 4 (j), The Constitutive Act of The African Union (2002).

Article 23, The Constitutive Act of The African Union (2002).

Article 23, The Constitutive Act of The African Union (2002).

Article 23, The Constitutive Act of The African Union (2002).

Magliveras K, 'The Sanctioning System of the African Union: Part success, part failure?' Paper Presented at An Expert Roundtable On "The African Union: The first ten years" (2011), 35.

52 Okumu W, 'The African Union: Pitfalls And Prospects For Uniting Africa', 95.
} 
provisions in urgent matters such as war are not utilised, it is even more unlikely that the less express provisions will be used in arguably less urgent matters of governance. The fact that African states know that there is little to no risk of any action in the case of bad governance, only serves to further hamper and discourage implementation of these policies.

\section{Factors Affecting the Ability of the AU to Implement}

The next step is to consider some of the impediments to implementation that the AU has faced. Rather than being exhaustive, this list is reflective of the impediments that are in some ways unique to the AU. The reasons proposed to explain the failure of the $\mathrm{AU}$ to implement its policies and programs that are explored herein are: the existence of several sub-regional bodies, the improper imitation of the EU model and, lastly, a perception that several governance policies are not African.

\section{i. Existence of Sub-Regional Bodies}

There are currently eight Regional Economic Communities (RECs) officially recognised by the AU. ${ }^{53}$ These communities are involved in coordinating AU member states' interests in wider areas such as peace and security, development and governance. ${ }^{54}$

One of the objectives of the AU is to coordinate and harmonize the policies between the existing RECs at the time of the AU's inception, and future RECs, for the gradual attainment of the objectives of the Union. ${ }^{55}$ However, this is easier said than done and the coordination of these efforts has often resulted in a tension of sorts as opposed to coordination. ${ }^{56}$ The multiplicity of sub-regional bodies operating in the continent has made it difficult for the AU to stamp its authority as the overall body in charge and hence for it to implement

53 These are the Arab Maghreb Union (AMU), Common Market for Eastern and Southern Africa (COMESA), Community of Sahel-Saharan States (CEN-SAD), East African Community (EAC), Economic Community of Central African States (ECCAS), Economic Community of West African States (ECOWAS), Intergovernmental Authority on Development (IGAD) and Southern African Development Community (SADC).

54 The African Union (AU) Commission, African Union Handbook, 2014, 118.

55 Article 3 (1), The Constitutive Act of the African Union (2002).

56 Woodrow Wilson International Centre for scholars, African Regional and Sub-Regional Organizations: Assessing their contributions to economic integration and conflict management, 2008, 8. 
its programs. The rivalry exists both between the $\mathrm{AU}$ and the various regional bodies and between the regional bodies themselves. ${ }^{57}$

Regarding the regional bodies that existed prior to the $\mathrm{AU}$, the issue of pulling of rank has been witnessed. For example, in the area of conflict management, blocs such as ECOWAS and SADC consider that they have greater conflict management experience than the $\mathrm{AU}$, which is a younger institution and therefore they consider their mandate to be superior. ${ }^{58}$

RECs also compete with each other in order to secure funding and exert political influence, which has made it difficult to harmonize the efforts of the various bodies given that they fear a substantial reduction in independence and direct support..$^{59}$

In addition, there is an overlap or conflict of obligations, which leads to wasted resources or counterproductive competition that distracts from collective efforts towards the common goals of the AU. ${ }^{60}$ Further, it becomes necessary to make decisions regarding the allocation of resources. Apart from facing multiple financial obligations, countries must also cope with different meetings, policy decisions, instruments, procedures, and schedules. Given the greater loyalty to sub-regional groups, African states would be more likely to direct their national resources and infrastructure towards implementing the policies of sub-regional blocs as opposed to those of the AU. Further, since financial resources are generally limited amongst African states, the effect of the monetary trade-off made is very real, given that there is unlikely to be disposable income to invest in several programs.

Using the example of Kenya, the dominance of the East African Community (EAC) as opposed to the $\mathrm{AU}$ is clear. Firstly, the EAC mandate has a government ministry dedicated to it. ${ }^{61}$ This means that EAC programs would potentially be implemented faster and better, since they are more closely monitored and have greater resources contributed to them. On the other hand the AU mandate falls under the Ministry of Foreign Affairs and International Trade whose mandate includes international trade, fulfilling Kenya's obligations to international organisations such as the UN, handling treaty negotiation and

\footnotetext{
Franke B, 'Competing Regionalisms in Africa and the Continent's emerging security architecture', 51. Okumu W, 'The African Union: Pitfalls and prospects for uniting Africa', 102.

Franke B, 'Competing Regionalisms in Africa and the Continent's emerging security architecture', 50. Franke B, 'Competing Regionalisms in Africa and the Continent's emerging security architecture', 44. The Ministry of East African Affairs, Commerce and Tourism.
} 
ratification and managing embassies of Kenya abroad, among other functions. ${ }^{62}$ Undoubtedly, the AU competes for space and resources in a crowded field. Further, Kenya's contributions to the EAC far outpace her contributions to the AU. In 2015, Kenya was expected to contribute slightly over nine million dollars towards the East African Community budget, ${ }^{63}$ while in 2014 she contributed approximately two million dollars towards the AU. ${ }^{64}$ Granted, this discrepancy in funding may be reflective of the fact that the EAC has fewer members and hence the financial burden may be heavier, while the AU has more members, which allows the financial burden to be spread out. However, even despite the difference in membership numbers, it could still be rightly argued that the EAC is more of a priority for Kenya than the $\mathrm{AU}$ is.

This is not unique to Kenya or East Africa. The divide between Northern Africa and Sub-Saharan African cannot be ignored with Northern African countries also being torn between their Arab identity and their African identity while West Africa is also divided along language groups.

One practical illustration of this is that within the last decade the engagement of African countries in the AU Commission's work in Addis Ababa has weakened. Nominations for AU Commissioner Posts also fell from eighty-seven in 2003 to thirty four in $2012 .{ }^{65}$ It is therefore clear that African states tend to find greater unity and integration within sub-regional bodies as opposed to the AU. This translates to implementation of policies and programs of sub-regional bodies at the expense of those of the AU.

It is important to consider that these regional loyalties are necessarily expected when one considers the differences among African countries. Some would argue that the identity achieved from factors such as religion and language supersedes any perceived African unity. Further, due to the vast population of Africa, approximately one billion people spread out over fifty-four countries, there cannot realistically be effective and strong bonds between the countries beyond neighbouring countries. ${ }^{66}$ For instance, many Northern Africans identify more with the Middle East due to their shared religion, culture, language and

62 'Core functions of Ministry of Foreign Affairs and International Trade of Kenya', Ministry for Foreign Affairs and International Trade, http://www.mfa.go.ke/aboutus.html on 13 September 2015.

63 Nkwame M, East Africa: EAC to Table 201 Billion - Budget, 11 May 2015 http://allafrica.com/ stories/201505111023.html on 24 November 2015.

64 The African Union (AU) Commission, African Union Handbook, 2014, 161.

65 CCR, The African Union at ten: Problems, progress and prospects, 2012, 16.

${ }_{66}$ Franke B, 'Competing regionalisms in Africa and the continent's emerging security architecture', 37. 
even skin tone. ${ }^{67}$ The lingual division can also not be ignored, with Anglophone and Francophone countries having had a rocky past. ${ }^{68}$

Other differences are more artificial, such as those along the lines of colonial masters. African countries colonized by the British are members of the Commonwealth and the influence of France in the affairs of her former colonies is widely documented. ${ }^{69}$ In fact France partially fuelled the Anglophone-Francophone tensions in the West African region. ${ }^{70}$ Once again, allegiance to the $\mathrm{AU}$ is weakened.

Therefore, it would seem that the priorities of African states are not aligned towards the AU and the body is often relegated to last place- both in loyalty and in allocation of resources and efforts. This hampers its abilities to implement (its) policies.

\section{ii. The False Allure of the EU Model}

Another impediment to implementation is that the AU has modelled its key institutions and strategies on those of the EU. ${ }^{71}$ While this was informed by the fact that the $\mathrm{EU}$ is the most advanced developed regional organization, ${ }^{72}$ this blind imitation failed to consider that the African continent and the European continent are substantially different. ${ }^{73}$ The AU cannot therefore automatically replicate the success of the EU simply by having similar institutions.

67 'How African Is North Africa?', BBC News, 23 January 2004, http://news.bbc.co.uk/2/hi/ africa/3421527.stm on 25 November 2015.

68 Consider the initial response to the creation of ECOWAS whereby the divide between Anglophone and Francophone West African states became clear. The creation of ECOWAS was intended to bridge the gap between the Anglophone and Francophone countries by closing the language barrier and incorporating within its framework previous initiatives that were exclusively francophone, for example UMOA (Union Monétaire Ouest Africaine). However, ECOWAS was viewed with suspicion and Francophone states were reluctant to join. In fact, Francophone States increasingly concentrated their cooperative efforts in more exclusive and smaller groupings. See more: Franke B, 'Competing regionalisms in Africa and the continent's emerging security architecture.'

69 An Al Jazeera Special Series news report titled 'The French African Connection' explored the relationship between France and her former colonies http://wwwaljazeera.com/programmes/ specialseries/2013/08/201387113131914906.html on 20 January 2016.

70 France was suspicious of the formation of ECOWAS and pressured West African states to reject the body, encouraging them to maintain Francophone economic cooperation. See more at: Franke $\mathrm{B}$, 'Competing regionalisms in Africa and the continent's emerging security architecture.'

71 CCR, The African Union at ten: Problems, Progress and prospects, 15.

72 Haynes J, Hough P, Malik S and Pettiford L, World Politics: International Relations and Globalisation in the 21st Century, 315

73 Haynes J, Hough P, Malik S and Pettiford L, World Politics: International Relations and Globalisation in the 21 st Century, 315. 
To begin with, the EU does not have an official sub-regional bloc. Further, even for the regional organisations and groups that (do) arise, the EU has a stable democratic framework to resolve and govern any institutional rivalries that may arise. ${ }^{74}$ The EU has a Committee of Regions, which gives regional organisations a voice in its running. The AU, on the other hand, does not have any such organisational structure and hence regional rivalries tend to be more pronounced and have more detrimental effects on the workings. ${ }^{75}$ Therefore, in the case of the $\mathrm{EU}$, unlike the $\mathrm{AU}$, the regional groupings enhance the work of the EU rather than compete with it.

Further, the EU operates on the principle of primacy of EU Law and, where there is a conflict of laws, the EU requires member states to defer to EU law at the expense of national law. ${ }^{76}$ Keeping in mind that law and policy are interconnected, the EU therefore has strong influence on the policies enacted in the states. In fact, the principle of primacy ensures that EU policies are implemented uniformly in all states, which enhances integration. ${ }^{77}$ Therefore, the principle of primacy makes the implementation of EU policies and programs much easier. One major difference is in fact the existence of EU Law, which serves as statute in the various countries. This is starkly different from the AU, which operates on the basis of agreements, declarations, treaties and other documents, which, while technically binding, do not serve as law in the various countries, at least not uniformly. ${ }^{78}$

The EU also tends to have a greater influence on member states and potential member states, given the draw of the potential economic and social benefits that the state acquires or may acquire from membership. ${ }^{79}$ The EU is therefore able to impose strict political and economic criteria for becoming a member and retaining membership. ${ }^{80}$ In contrast, the economic benefits of being a member of the AU are not as pronounced and, thus, the institution does not have an upper hand in bargaining to ensure that its policies are implemented. ${ }^{81}$

\footnotetext{
74 Franke B, 'Competing regionalisms in Africa and the continent's emerging security architecture', 40.

75 Franke B, 'Competing regionalisms in Africa and the continent's emerging security architecture', 40.

76 Kruis T, 'Primacy of European Union law -from theory to practice' Ritsumeikan Law Review (2011), 270.

77 Kruis T, 'Primacy of European Union Law -from Theory to Practice', 272.

78 Without delving into a discussion on monism and dualism, it is important to note that for some African countries ratified treaties automatically form part of the law of the country. However, even in these countries, where there is a conflict between such treaty and national law, national law prevails.

79 Haynes J, Hough P, Malik S and Pettiford L, World Politics: International relations and globalisation in the 21st Century, 313.

80 Haynes J, Hough P, Malik S and Pettiford L, World Politics: International relations and globalisation in the 21st Century, 313.

81 For instance trade on the continent is still primarily competitive (similar goods and similar markets)
} 
Further, the EU started off with a significantly lower number of members, six countries, and was able to achieve its successful integration at a gradual pace. ${ }^{82}$ The AU, on the other hand, set out to achieve its integration goals with fifty-three members ${ }^{83}$ In line with this, the AU set out to establish, at its inception, bodies that the EU established over a number of years. ${ }^{84}$ In addition to this, the EU began with more mature and affluent nations, while the AU was formed with emerging, and, in many cases fragile, nations that were considerably poorer. ${ }^{85}$

Therefore, modelling the AU after the EU without regard for these structural differences between the two continents has presented a problem for the AU. The structural make-up of the AU therefore affects its ability to implement its programs. Granted that it is no longer possible to go back, it is possible to revise existing structures and processes to compensate for these differences and reflect the reality of the African continent.

\section{iii. 'Africanisation' of Solutions}

Over the past few years there have been increasing calls to provide 'African solutions to African problems.' These calls stem from the perception that for a long time, there have been attempts to solve African problems with Western solutions.

Africa's relations with the international legal regime have not been entirely cordial with the memories of colonialism still fresh ${ }^{86}$ and imperialism still arguably alive. For this reason, African states have often been sceptical of and hostile to suggestions by Western countries of solutions to their problems. ${ }^{87}$ This translates to reluctance in implementing programs suggested by these powers.

In order to rectify this, the AU has become increasingly innovative in its attempts to shrug off this influence and instead to assert Africa's position as one of equal standing and sovereignty. There is therefore a tendency to be more inward-

as opposed to complementary. States therefore find greater trade partnerships externally than from within.

82 Barbarinde $\mathrm{O}$, 'The EU as a model for the African Union: The limits of imitation', 7 Jean Monnet/ Robert Schuman Paper Series (2007), 9.

83 The Constitutive Act of the African Union (2002), Preamble.

84 Barbarinde $\mathrm{O}$, 'The EU as a Model for the African Union: The limits of imitation', 10.

85 Barbarinde $\mathrm{O}$, 'The EU as a Model for the African Union: The limits of imitation', 9.

86 Consider the debate surrounding the establishment of the African Court of Justice and Human Rights in 2014, which was rife with accusations of imperialism.

${ }^{87}$ Nmehielle V and Katherine A, 'The African Peer Review Mechanism under the African Union and its initiative: The new partnership for Africa's Development', 240. 
looking when providing solutions. Such Africanisation, characterized by building national capacity in the form of think-tanks, universities and policy makers, ${ }^{88}$ could help accelerate the implementation of Africa's reform programs. ${ }^{89}$

Therefore it is clear that these three impediments are largely unique to the $\mathrm{AU}$ (perhaps even characteristic of the institution) and must be considered when analysing the pitfalls of the organisation.

\section{iv. The New Partnership for Development (NEPAD) and the African Peer Review Mechanism (APRM)}

The implementation gaps existing within a specific AU program, the African Peer Review Mechanism (APRM), are not to be shunned. Perhaps the boldest attempt to provide an African solution to an African problem was pioneering the APRM, which is a program under The New Partnership for Africa's Development (NEPAD).

NEPAD is an economic development program of the AU adopted at the thirty-seventh session of the Assembly of Heads of State and Government in July $2001 .^{90}$ It is intended to address critical challenges facing the continent such as poverty, development and Africa's marginalisation internationally. ${ }^{91}$

In 2002, at a NEPAD Heads of State Implementation Committee (HSIC) members of the organization approved a Declaration on Democracy, Political, Economic and Corporate Governance. This Declaration, together with the APRM, was then submitted to the AU Summit as the final governing authority of NEPAD. Therefore, in order to participate in the APRM, member states must sign onto the NEPAD Declaration. ${ }^{92}$

The APRM is considered to be one of the most innovative aspects of NEPAD. ${ }^{93}$ Launched in 2003, it is a process for assessing political, economic, and corporate governance and socio-economic development in participating countries. ${ }^{94}$ Through the APRM, African countries submit to and facilitate

\footnotetext{
CCR, The African Union at ten: Problems, progress, and prospects, 16.

CCR, The African Union At Ten: Problems, Progress, and Prospects, 16.

Cilliers J, 'NEPAD’s Peer Review Mechanism’ Institute for security studies (2002), 2.

NEPAD, http://www.nepad.org/history on 13 December 2015.

Cilliers J, 'NEPAD’s Peer Review Mechanism', 3.

Cilliers J, 'NEPAD's Peer Review Mechanism', 1.

${ }^{4}$ Killander M, 'The African Peer Review Mechanism and Human Rights: The first reviews and the way forward' 30, Human Rights Quarterly (2008), 41.
} 
periodic peer reviews, and accept to be guided by agreed parameters for good governance at both the political and economic levels. ${ }^{95}$ The program is designed to help African states create an enabling environment for sustainable development and good governance. Africa is the only region in the world with an extensive governance peer review mechanism voluntarily agreed to by the member states. ${ }^{96}$

It is an ambitious development project that emanated from the philosophy of African renaissance and rebirth. ${ }^{97}$ The program was created as a collective African response to globalisation and was intended to assert that Africa is equal to the rest of the world, and that there was a need to establish partnerships with developed countries and international financial institutions, on the basis of mutual obligations and commitments. ${ }^{98}$

At its inception there was great excitement and hope about the potential power of the APRM as a tool to ensure good political and economic governance on the continent. Most good-governance initiatives in Africa are perceived as being the wishes of Western donors and international financial institutions which are similarly seen as proxies of these Western powers. It was hoped that the APRM would be insulated from some of the usual problems that befall other attempts to improve governance in Africa. The reasons were that, firstly, it was a pioneering concept by African states, therefore the accusations of Western imperialism or imposition of Western standards could not be fronted. It is the African states that not only chose the areas to be assessed but also chose the manner of assessment- the entire process is guided by fellow African states. From this resounding endorsement of autonomy, one would imagine that the APRM would be taken more seriously than any other good-governance programs. Secondly, it is a volunteer program hence it was hoped that the states involved would be more likely to implement the policy. It was assumed that a country that voluntarily accepted the program would implement policies as the criticisms that would arise would not be unwanted or unwelcome, but rather a sign of wanting to improve. Thirdly, several of the APRM's objectives lie in the 'soft' areas of socio-

95 Cilliers J, 'NEPAD's Peer Review Mechanism', 3

96 Rashed A, The African Peer Review Mechanism (APRM): Its role in fostering the implementation of sustainable development goals', UN High Level Political Forum on Sustainable Development (HLPF), New York, 30 June 2015.

97 Nmehielle V and Katherine A, 'The African Peer Review Mechanism under the African Union and its initiative: The new partnership for Africa's Development', 242.

98 Nmehielle V and Katherine A, 'The African Peer Review Mechanism Under the African Union and its Initiative: The new partnership for Africa's development', 242. 
economics, as opposed to the more controversial areas of conflict and war. ${ }^{99} \mathrm{It}$ was therefore assumed that the APRM would easily receive support.

However, twelve years after its inception, the enthusiasm has largely waned with hardly any convincing evidence of its success despite the favourable conditions for its growth. For instance, the countries that have undergone the process had little or nothing to show by way of improved ranking in the 2014 Ibrahim Index of African Governance. ${ }^{100}$ It would have been assumed that a program exclusively dedicated to solving governance programs would result in better governance rating for countries that participate in it. The results are, however, a mixed bag and there is little-to-no linkage between the APRM process and any improved governance in a country. ${ }^{101}$ Of course, this has done little to win over the sceptics of the program and has put the APRM on the defensive to justify the goodwill extended to it at its inception ${ }^{102}$ as well as its continued existence. However, as will be seen, the APRM is a viable project that mostly fails, like many AU programs, at the last leg of the process-implementation.

\section{v. The APRM Process}

The APRM broadly focuses on the area of governance and has four main thematic areas: Democratic and Political Governance, ${ }^{103}$ Economic Governance

99 Nmehielle V and Katherine A, 'The African Peer Review Mechanism Under the African Union and its Initiative: The new partnership for Africa's development', 241.

100 Gruzd S and Turianskyi T, 'Do African Union Governance reviews work?' South African Institute of International Affairs, 20 October 2014 http:/ / www.saiia.org.za/opinion-analysis/do-african-uniongovernance-reviews-work on 11 December 2015.

101 Gruzd S and Turianskyi T, 'Do African Union Governance Reviews Work?' South African Institute of International Affairs, 20 October 2014http:/ / www.saiia.org.za/opinion-analysis/do-african-uniongovernance-reviews-work on 11 December 2015

102 Gruzd S, 'Africa's evolving governance architecture: Reflections on the African Peer Review Mechanism' Centre for Policy Studies, 2009, 10.

103 This refers to issues such as prevention and reduction of intra- and inter-state conflicts; Constitutional democracy, including periodic political competition and opportunity for choice, the rule of law, citizen rights, and supremacy of the Constitution; promotion and protection of economic, social, and cultural rights, civil and political rights as enshrined in African and international human rights instruments; Uphold the separation of powers, including the protection of the independence of the judiciary and of an effective legislature; Ensure accountable, efficient and effective public office holders and civil servants; Fight corruption in the political sphere; Promotion and protection of the rights of women, children and young persons and vulnerable groups including internally displaced persons and refugees. 
and Management, ${ }^{104}$ Corporate Governance ${ }^{105}$ and Socio-Economic Development. ${ }^{106}$ There are four kinds of review available under the APRM framework. The first, country review, which is the base review, is carried out within eighteen months of a country becoming a member of the APRM. The second is a periodic review, which takes place every two to four years. The third is a review that can be solicited by a member country for its own reasons. The fourth type consists of reviews that can be instituted by the APR Forum in a spirit of helpfulness to the government of a participating country where there are signs of impending political or economic crisis. ${ }^{107}$

The structure of the APRM consists of the Committee of Participating Heads of States (APR Forum) as the highest decision-making authority; the Panel of Eminent Persons (APR Panel) as the overseeing body; the APRM Secretariat (APR Secretariat); and the Country Review Team (APR Team). ${ }^{108}$

The review process has five steps: First, a background study of the country in question is conducted. This step requires that the country conducts a self-assessment and produces a preliminary Plan of Action. This assessment is guided by a questionnaire provided by the APRM. The different states are given leeway to determine how to conduct this self-assessment. For instance, Ghana convened a national governing council made up of independent professionals, while

104 This includes efforts to promote macroeconomic policies to support sustainable development; Implement sound, transparent and predictable government economic policies; Promote sound public finance management; Fight corruption and money laundering; Accelerate regional integration by participating in the harmonization of monetary, trade and investment policies.

105 This includes efforts to promote an enabling environment and effective regulatory framework for economic activities; Ensure that corporations act as good corporate citizens with regard to human rights, social responsibility and environmental sustainability; Promote adoption of codes of good business ethics in achieving the objectives of the corporation; Ensure that corporations treat all their stakeholders (shareholders, employees, communities, suppliers and customers) in a fair and just manner; Provide for accountability of corporations, directors and officers.

106 This includes efforts to promote self-reliance in development and build capacity for self-sustaining development; Accelerate socioeconomic development to achieve sustainable development and poverty eradication; Strengthen policies, delivery mechanisms, and outcomes in key social areas including education and combating of HIV/AIDS and other communicable diseases; Ensure affordable access to water, sanitation, energy, finance (including micro-finance), markets, ICT, shelter, and land for all citizens, especially the rural poor; Progress towards gender equality in all critical areas of concern, including equal access to education for girls at all levels; Encourage broadbased participation in development by all stakeholders at all levels.

107 Mangu M, 'The African Union and the promotion of democracy and good political governance under the African Peer-Review Mechanism: 10 years on', 6(1) Africa Review, (2014), 64- 65.

108 See 'The African Peer Review Mechanism organisation and process, NEPAD/HSCIC-3-2003/ APRM/Guideline/ O\&P, 2003. 
Kenya formed an Inter-Ministerial Task Force for the same. ${ }^{109}$ This background research is supposed to involve civil society, business and government. The purpose is to assess the country's strengths and weaknesses on the issues contained in the review and to identify gaps in governance. ${ }^{110}$

The second stage is the country review mission whereby eminent panel members of the APRM ${ }^{111}$ lead missions to the various review countries. This independent team of African experts visits the country to do its own assessment. ${ }^{112}$ The purpose of these missions is to "learn about the perspectives of the different stakeholders on governance in the country and to clarify the issues identified in the Issues Paper that are not taken into account in the preliminary Programme of Action of the country, and to build consensus on how these could be addressed." 113 It is at this stage that consultations are held with the government and other entities in the state.

The third step in the process is the writing of the country review report. This report is a summary of the country's self-assessment, the findings of the mission trip as well as the recommendations of the Panel. ${ }^{114}$ The report is crucial as it from this document that the National Plan of Action (NPoA) stems.

The fourth step in the process is the tabling of the report before the APRM Forum of the Heads of State and Government. The eminent person in charge of the country presents this report. The heads of state then debate the report. This is the actual manifestation of the peer-review nature of the process.

The fifth and final stage is the public tabling of the report in key regional and sub-regional structures six months after the APR Forum has considered it.

\section{vi. National Plan of Action (NPOA)}

The APRM has experienced difficulties at each of these five stages. For instance, there have been complaints that the self-assessment questionnaire pro-

109 Killander M, 'The African Peer Review Mechanism and Human Rights: The first reviews and the way forward', 49.

110 Gruzd S, 'Peace, security and the African Peer Review Mechanism: Are the tools up to the task?' African Security Review, 56.

111 For instance, Ms. Graca Machel led the country mission in Kenya

112 Gruzd S, 'Peace, security and the African Peer Review Mechanism: Are the tools up to the task?', 56.

113 'The African Peer Review Mechanism organisation and process', NEPAD/HSCIC-32003/APRM/ Guideline/ O\&P, 2003.

114 Gruzd S, 'Peace, security and the African Peer Review Mechanism: Are the tools up to the task?' 56. 
vided is too vague, complicated, and repetitive and fails to ask the pertinent questions. ${ }^{115}$ There have also been criticisms that some countries have excluded civil society in formulating country reports, ${ }^{116}$ despite the fact that it is a crucial actor. Further the presentations of the reports before the Forum have also been faulted as failing to be critical enough and place states on the spot.

However, the issue of this paper is on the NPoA. This document is the culmination of the research and assessment period and is the guiding light for going forward. A weak, vague or untrue NPoA is a drawback to the entire process. While the actual review process ends after about eighteen months, the NPoA is the document that must outlive the actual review process and be implemented in the coming years.

However, this is not the case. The NPoAs produced by the countries have often been little more than policy documents whose recommendations remain on paper. The aim of the APRM process is not simply to document the governance problems facing various African states but rather to solve these problems. If the problems surrounding the NPoA are not resolved, then the APRM process will remain a documentation process.

The NPoAs drafted suffer from several deficiencies. Firstly, they are not truly reflective of the reality on the ground. In some APRM countries, the civil society has been left out of the review process. ${ }^{117}$ This means that some of the NPoAs are not a complete reflection of the situation. This hinders the actual implementation of the document since, in a bid to paint a rosy picture, serious issues have been overlooked.

The second deficiency in the NPoAs has been that the recommendations have been largely aspirational with the states giving no plans on how to implement them. One clear illustration of this is the assessment of the financial implications of implementing the plan. For instance, it was estimated that the cost of implementing the NPoA programs are ninety five million US dollars for Rwanda, and five billion US dollars for Ghana as well as for Kenya. ${ }^{118}$ It is quite

115 Killander M, 'The African Peer Review Mechanism and Human Rights: The first reviews and the way forward', 74 .

116 Killander M, 'The African Peer Review Mechanism and Human Rights: The First Reviews and the way forward', 52 .

117 Killander M, 'The African Peer Review Mechanism and Human Rights: The First Reviews and the way forward', 52 .

118 Killander M, 'The African Peer Review Mechanism and Human Rights: The first reviews and the way forward', 70-71. 
clear that these countries lack any such resources. The assumption therefore is that these recommendations were nothing more than a wish-list created by the states with almost no intention of implementing them. This assumption is further supported by the fact the NPoAs had no indications of how this funding would be sourced.

The NPoAs also largely fail to identify how the existing state institutions will be integrated into the implementation process. What cannot be ignored is the fact that national institutions may exist whose mandate is similar or even identical to some areas of the APRM mandate, for instance National Human Rights Institutions (NHRIs) and the Ombudsman offices.

From the foregoing establishments, it is clear that the NPoAs need to be clearer and more specific to guarantee accountability and enforcement.

\section{a) The APRM and the Three Impediments to Implementation}

At this point it is important to consider the APRM in light of the three impediments to implementation proposed in this paper, that is: the existence of sub-regional bodies, the improper use of the EU model and the lack of African solutions. The APRM is also a victim of sub-regional competition. While the APRM is the first peer-review mechanism it is not the first mechanism set up to monitor issues of governance on the continent. Several sub-regional bodies have such mechanisms on a number of issues such as peace and security, human rights and economic policy. ${ }^{119}$ It therefore seems that the APRM, like many AU programs could suffer from the negative effects of regional supremacy battles.

It is important to note that these three impediments may not be the exact reasons for the failure of the APRM, and other impediments may play a larger role.

With regard to replicating the EU model, the APRM cannot be compared in this regard as it is the first tool of its kind used to assess governance, and the EU has no comparable model.

The standing of the APRM with regard to its acceptance as an African solution is the most perplexing of the three. As already noted, the APRM was conceived as an African solution to an African problem and was touted as the first of its kind. However, some detractors have taken issue with the funding of the

119 Killander M, 'The African Peer Review Mechanism and Human Rights: The first reviews and the way forward', 47. 
APRM- the program is largely funded by donors. ${ }^{120}$ Some have used this to argue that the APRM could be used as a tool of these governments. ${ }^{121}$ Indeed, these were the reasons given by countries that were reluctant to accede to the program. However, these accusations are dishonest. Nearly all African development projects and programs are funded partly by donors. In fact, even national budgets on the continent are funded by donor money. While funding could jeopardise autonomy, it would be odd for African countries to use this argument to attack the APRM while failing to consider the economic reality of most AU programs and indeed their own national budgets. Therefore, the criticisms of the APRM along these lines, while possibly valid, can be viewed as unfair in light of the reality of funding on the continent.

\section{Conclusion}

A well-functioning and effective AU is crucial if Africa hopes to achieve her political, social and economic goals. With fifty-four countries and over one billion people of different ethnic, cultural, religious and language groups under its umbrella the $\mathrm{AU}$ must necessarily serve as the coordinating institution that mobilises Africans to achieve these goals. ${ }^{122}$ In order that these goals be achieved, the institution must show a commitment to implementing its policies.

This paper has explored the history of the $\mathrm{AU}$ as well as the promise that the institution held. Three factors are helpful in explaining the failure of the AU to implement its policies (and how the APRM measures against these factors), the APRM process: the weaknesses in the implementation of the APRM and the possible remedies to these weaknesses. In doing so, the paper has illustrated that the Achilles heel- the fatal weakness- of the AU is its inability to implement its programs.

The AU can be termed as the sleeping lion of global politics. It must not only 'talk the talk' but also 'walk the walk.' Implementing its policies will raise the credibility and profile of the AU giving it a larger say in world politics. More importantly, an effective and functional AU serves to benefit the people of the African continent. An AU that follows up on member states helps to protect

\footnotetext{
120 Mathoho M, 'An African Peer Review Mechanism: A panacea for Africa's governance challenges?’ 11.

121 Mathoho M, 'An African Peer Review Mechanism: A panacea for Africa's governance challenges?' 11.

122 Kimenyi M, 'An African Union for an emerging Continent: Reforms to increase effectiveness' The Brookings Institution: Africa Growth Initiative, 2015, 29.
} 
citizens from the excesses of their governments and serves to remind African governments that they are accountable. An effective AU is one that can successfully integrate and rightfully take its rightful place as a powerhouse of economic union in the world.

Without any follow-through, the potential of the AU remains on paper and contained in well-written policy papers but is absent in the daily lives of Africans.

\section{Recommendations}

In order to close these implementation gaps, the drafting of NPoAs needs to be considered.

Firstly it is necessary to require that states provide a financial impact assessment together with their report. Although it is possible that after the review process, the APRM could mobilize funding for countries that wish to implement their reports, ${ }^{123}$ financial impact assessments help to gauge the seriousness of the states. States would be unlikely to attach wild financial impact assessments since these would bring into question the seriousness of the states. This deters states from simply listing utopian goals whereas they should confine themselves to actual achievable objectives. The states must also be required to give suggestions on where this funding may be sourced. This would make states consider more carefully what they put in the action plans.

On the extreme end, this may induce conservatism and make states wary of making several recommendations. The balance must be struck because some recommendations, though not entirely realistic, are needed since they are aspirational and serve to create an ideal standard; however, the entire action plan cannot be simply aspirational. To do this, states need to receive support from the Panel in creating more realistic plans and recommendations in the NPoA. ${ }^{124}$

Second, there should be mechanisms for civil society to report on their involvement in the entire APRM process and to lodge formal complaints if they are being sidelined. These complaints should be considered when drafting the county report and presenting it to the forum.

\footnotetext{
123 Nmehielle V and Katherine A, 'The African Peer Review Mechanism under the African Union and its initiative: The New Partnership for Africa's Development', 245.

124 Killander M, The African Peer Review Mechanism and Human Rights: The first reviews and the way forward', 70 .
} 
Third, the role of the forum in critiquing the NPoAs must be strengthened. The forum is the point at which the peer-review nature of the process emerges. It is the stage at which different states must ask difficult questions of their peers. However, what has emerged seems to be a reluctance to be overly critical and, in some cases, even glaring discrepancies and omissions have been ignored. ${ }^{125}$ While members of the Pan-African Parliament are invited to comment on the report ${ }^{126}$ one suggestion is to open up the forum process to other actors- such as Non-Governmental Organizations. The APRM was conceived as a state-to-state critique and actors such as civil society still form part of the state. In its current form the process may not bear much fruit unless and until governments are more willing to be critical of themselves and of one another. Non-government actors are usually more willing to ask the harder questions and this would help the process. Encouraging inclusiveness and even popularizing the initiative would help the process too, since people would take ownership of it. ${ }^{127}$ The involvement of the non-state actors would also increase calls for accountability. While this may scare off African governments who are generally wary of civil society, it would be an important tool to consider in ensuring that actual peer review takes place.

125 Killander M, The African Peer Review Mechanism and Human Rights: The first reviews and the way forward', 53.

126 Killander M, 'The African Peer Review Mechanism and Human Rights: The first reviews and the way forward', 53.

127 Mangu A, 'The African Union and the promotion of democracy and good political governance under the African Peer-Review Mechanism: 10 years', 68. 